\title{
Effect of a Monensin Controlled Release Capsule on Metabolic Parameters in Transition Dairy Cows
}

\author{
T. F. Duffield, ${ }^{\star}$ S. LeBlanc, ${ }^{\star}$ R. Bagg, † K. Leslie, ${ }^{\star}$ J. Ten Hag, $\ddagger$ and P. Dick† \\ *Department of Population Medicine, \\ University of Guelph, Guelph, Ontario N1G 2W1 \\ †Provel Division of Eli Lilly Canada Inc., \\ 150 Research Lane, Suite 120, Guelph, Ontario N1G 2T4 \\ ‡Ontario Ministry of Agriculture and Rural Affairs, Fergus, Ontario
}

\section{ABSTRACT}

A prospective field study involving 251 Holstein cows and heifers from five dairy farms near Guelph, Ontario, Canada, was conducted to measure the effect of monensin delivered in a controlled release capsule $3 \mathrm{wk}$ precalving on metabolic function in dairy cows immediately pre- and postcalving. At 3 wk before expected calving, cows were randomly assigned to receive either a controlled release capsule containing monensin or to serve as negative controls. Cows were blood sampled once per week precalving and once in the week following calving, at the same time of day and the same day of the week. Serum was evaluated for $\beta$-hydroxybutyrate (BHBA), nonesterified fatty acids (NEFA), cholesterol, urea, glucose, calcium, and phosphorus. Monensintreated cows had significantly decreased NEFA and BHBA and significantly increased concentrations of serum cholesterol and urea in the week immediately precalving. No effect of treatment was observed for calcium, phosphorus, or glucose in the precalving period. After calving, concentrations of phosphorus were lower and BHBA tended to be lower, and cholesterol and urea were higher in monensin-treated cows. There was no effect of treatment on NEFA, glucose, or calcium in the first week postcalving. Monensin treatment administered precalving significantly improved indicators of energy balance in both the immediate precalving and postcalving periods. The findings indicate better energy metabolism in monensin-treated cows as they approach calving. Improvement of energy balance before calving is important for the prevention of energy associated metabolic diseases, such as retained placenta, clinical ketosis, and displaced abomasum, which might occur immediately postcalving.

(Key words: controlled-release capsule, metabolic parameters, monensin, transition dairy cows)

Received August 29, 2001.

Accepted December 7, 2001.

Corresponding author: T. Duffield; e-mail: tduffiel@uoguelph.ca.
Abbreviation key: $\mathbf{C R C}=$ controlled-release capsule, DA = displaced abomasum.

\section{INTRODUCTION}

Monensin is an ionophore antibiotic that alters VFA production in the rumen in favor of propionate (Richardson et al., 1976). Propionate is a major precursor for glucose in the ruminant. Monensin is not currently approved for lactating dairy cattle in the United States, but is legal in several other countries. For example, in Canada a monensin-controlled release capsule (CRC) is approved as an aid in the prevention of subclinical ketosis in lactating dairy cattle. This device delivers $335 \mathrm{mg}$ of monensin per day for $95 \mathrm{~d}$ (Provel, Veterinary Reference Guide, 1998). A monensin CRC has been shown to decrease the incidence of subclinical ketosis, displaced abomasum (DA), and multiple illness when administered to dairy cows 3 wk before calving (Duffield et al., 1999). It is likely that these effects on clinical health are mediated by improved energy balance in monensin-supplemented cows. This notion is supported by studies that have shown improvements in energy indicators such as increased glucose and decreased BHBA postcalving (Abe et al., 1994; Duffield et al., 1998a; Green et al., 1999). However, limited published information is available on metabolic changes associated with monensin immediately precalving to support its administration in the dry period, as opposed to administration at or after calving. Green et al. (1999) reported a tendency for lower BHBA concentrations precalving in cows given a monensin CRC, but they did not measure NEFA in that study. Stephenson et al. (1997) found both significantly lower BHBA and NEFA precalving in cows receiving a monensin CRC at 50 $\mathrm{d}$ precalving. However, this study utilized herds from Australia under different management conditions (pasture) than typical North American dairies.

The purpose of this study was to evaluate the metabolic impact of a monensin controlled release capsule administered 3 wk before calving on serum biochemis- 
try parameters in the weeks immediately pre and postcalving.

\section{MATERIALS AND METHODS}

Five Holstein dairy herds near Guelph, Ontario were selected for the study. Two herds were free-stall operations, and the other three herds were tie-stall dairies. All herds utilized two dry cow feeding groups (far-off and close-up). Lactating cow diets were typical of SW Ontario dairies and included corn silage and haylage as the forage base, high moisture corn for the energy component, and a commercial supplement with soyabean meal as the major protein source. Specific diet formulations for each farm were unavailable. Three herds fed a TMR, while the other two herds utilized a component feeding system. The herds using a TMR diet fed cows twice per day with the first feeding occurring after the morning milking. Herds that had a component feeding system offered forages twice per day and divided concentrate feedings into 3 to 4 times per day allotments. Each herd was visited on the same day each week at approximately the same time of day by a field study technician. Both cows and first lactation animals were eligible for the trial. A list of expected calving dates was generated and animals were assigned to either a monensin CRC or no treatment based on random number tables within each herd. Treatment was administered on the day of enrollment $3 \mathrm{wk}$ before expected calving date. Enrollment of cows varied with each farm due to herd size and commencement on the study. A total of $13,24,134,42$, and 38 cows were enrolled on the five participating dairies.

All animals were assigned a BCS ( 1 to 5 scale) by the field study technician once on the day of enrollment in the study ( $3 \mathrm{wk}$ before the expected calving date). A free-flow urine sample was collected (if possible) $1 \mathrm{wk}$ before expected calving date, and at weekly intervals if the cow had not calved, for measurement of urine $\mathrm{pH}$ and urine ketones (Acetest, Bayer, Etobicoke, Ontario, Canada). Blood samples were obtained from the coccygeal vein and collected into a $10-\mathrm{ml}$ evacuated tube without anticoagulant. Blood samples were collected at 1 wk before expected calving date, at weekly intervals if the cow had not calved, and at $d 1$ to 7 postpartum. Samples were allowed to clot and centrifuged, and serum was separated and frozen. Frozen serum was submitted to the Animal Health Laboratory, University of Guelph within 2 wk of collection for the measurement of serum BHBA, NEFA, glucose, cholesterol, urea, calcium, and phosphorus using a serum autoanalyzer (Hitachi, model 911). Milk samples were collected once between $d 1$ to 7 postpartum in the morning for measurement of milk ketones using two different ketone tests [Sanketopaper (Sanwa Kagaku Kenkyusho Company, Nagoya, Japan] and Pink Milk (http://www.profsproducts.com, Germany). Sanketopaper is a semi-quantitative test for BHBA in milk manufactured in Japan by the Sanwa Kagaku Kenkyusho company. In Europe the test is marketed by Intervet and it is called Ketolac BHB. It is called Keto-Test in Canada and is distributed through Elanco Animal Health. Pink milk is a qualitative test for acetone and acetoacetate in milk. All milk ketone testing was conducted within $4 \mathrm{~h}$ of collection.

\section{Statistical Analysis}

All statistical analyses were conducted with SAS version 8.0 for Windows. Both NEFA and BHBA data were right skewed and a logarithmic transformation was applied for each to normalize the data. All other metabolic parameter data had a normal distribution. Evaluation of treatment effects on metabolic parameters was performed using a generalized linear model (proc genmod). All analysis controlled for initial BCS, days from sample to calving, and parity as covariates in each linear model. Additionally, the correlation of cows within herd was accounted for by including herd as a random effect, where generalized estimating equations are used specifying a common correlation structure within each herd.

The effect of treatment on the incidence of subclinical ketosis were analyzed with logistic regression, also using the generalized modeling procedure (proc genmod), specifying the logit link function, binary distribution and exchangeable correlation structure for the random herd effect.

\section{RESULTS}

In total, 128 cows received a monensin CRC and 123 cows served as negative controls. Including both treatment groups, there were 84 animals in first lactation, 57 cows in second lactation, and 110 cows were in third lactation or greater. The mean lactation number (2.10) and mean BCS at the time of enrollment (3.67) did not differ between treatment groups. A mean of $22 \mathrm{~d}$ existed between the time of treatment administration and calving. This variable was not significant in any of the statistical models. The precalving data were collapsed to include only one sample per cow in the time within 7 $\mathrm{d}$ before the actual calving date. The precalving sample was obtained at a mean of $3.6 \mathrm{~d}$ before calving, whereas the postcalving sample occurred at an average of $3.5 \mathrm{~d}$ after calving. Eight animals in each treatment group were removed from their herd of origin between the precalving and the postcalving blood sample.

Analysis of the precalving serum data revealed significant effects of monensin CRC on BHBA, NEFA, cho- 
Table 1. Least squares means from generalized linear models for serum biochemical parameters in cows within 1 wk precalving that were either treated 3 wk precalving with a monensin-controlled release capsule (CRC) or served as negative controls. ${ }^{1}$

\begin{tabular}{|c|c|c|c|c|c|}
\hline \multirow[b]{2}{*}{ Parameter } & \multicolumn{2}{|c|}{$\begin{array}{l}\text { Monensin CRC } \\
\quad(\mathrm{n}=128)\end{array}$} & \multicolumn{2}{|c|}{$\begin{array}{l}\text { Negative control } \\
\quad(\mathrm{n}=123)\end{array}$} & \multirow[b]{2}{*}{$P$-value } \\
\hline & Mean & SE & mean & SE & \\
\hline $\mathrm{BHBA}(\mu \mathrm{mol} / \mathrm{L})$ & 606 & 25.1 & 712 & 9. & 0.005 \\
\hline NEFA (U/L) & 0.44 & 0.029 & 0.53 & 0.042 & 0.02 \\
\hline Glucose $(\mathrm{mmol} / \mathrm{L})$ & 3.73 & 0.069 & 3.82 & 0.065 & 0.18 \\
\hline Cholesterol (mmol/L) & 2.07 & 0.040 & 2.00 & 0.040 & 0.004 \\
\hline Urea $(\mathrm{mmol} / \mathrm{L})$ & 5.51 & 0.224 & 5.04 & 0.314 & 0.001 \\
\hline Calcium (mmol/L) & 2.37 & 0.194 & 2.35 & 0.026 & 0.487 \\
\hline Phosphorus (mmol/L) & 1.96 & 0.047 & 1.90 & 0.036 & 0.08 \\
\hline
\end{tabular}

${ }^{1}$ Models using proc genmod (SAS) included parity, body condition score precalving, days from sample to calving, and the random effect of herd.

lesterol, and urea (Table 1). BHBA was lower $(P=$ $0.005)$, NEFA was lower $(P=0.02)$, cholesterol was higher $(P=0.004)$, and urea was higher $(P=0.001)$ in monensin CRC-treated cows compared with the negative control animals in the week immediately precalving. No significant differences were found for glucose, calcium, or phosphorus precalving.

The results of analysis on the blood sample obtained in the $7 \mathrm{~d}$ immediately postcalving identified significant treatment effects on serum cholesterol, urea, and phosphorus (Table 2$)$. Cholesterol was higher $(P=0.0001)$, urea was higher $(P=0.004)$, and phosphorus was lower $(P=0.01)$ in monensin CRC treated cows compared with negative control cows. There was a tendency for monensin CRC treated cows to have lower BHBA $(P=$ $0.06)$. No significant treatment effects were noted for NEFA, glucose, or calcium.

There were $12(8.9 \%)$ positive urine ketone tests in 134 cows precalving. Monensin CRC-treated cows were significantly less likely to have a positive urine ketone test precalving $(P=0.03)$. Only $3(4.1 \%)$ urine ketone tests were positive in the monensin CRC-treated cows.
A total of 134 (53\% of cows) urine samples were obtained in the $7 \mathrm{~d}$ before calving. The median urine $\mathrm{pH}$ was 8.2 with a range of 6.4 to 9.3. Monensin CRC was not associated with urine $\mathrm{pH}$.

Milk samples postcalving were tested with the Sanketopaper and Pink milk ketone tests. Results for two cut-off levels for Sanketopaper corresponding to $\geq 100$ and $\geq 200 \mu \mathrm{mol} / \mathrm{L}$ of BHBA in milk (according to the manufacturer of the test) were recorded. Because serum BHBA was quantified at the same time that the milk samples were collected, the sensitivity and specificity of the Sanketopaper test were calculated using 1400 $\mu \mathrm{mol} / \mathrm{L}$ serum BHBA as the gold standard. The sensitivity and specificity were 81 and $62.5 \%$ respectively at the lower cut-off, and $73 \%$ and $83 \%$ respectively at the higher cut-off. Cows treated with the monensin CRC were significantly less likely to have a positive Sanketopaper test at either cut-off value using either simple chi square or logistic regression (Table 3).

The Pink milk test was also compared in performance to the serum BHBA at a cut-off of $1400 \mu \mathrm{mol} / \mathrm{L}$. The sensitivity for this test was $23 \%$ and the specificity

Table 2. Least squares means from generalized linear models for biochemical parameters in cows within $1 \mathrm{wk}$ postcalving that were either treated $3 \mathrm{wk}$ precalving with a monensin-controlled release capsule (CRC) or served as negative controls. ${ }^{1}$

\begin{tabular}{|c|c|c|c|c|c|}
\hline \multirow[b]{2}{*}{ Parameter } & \multicolumn{2}{|c|}{$\begin{array}{l}\text { Monensin CRC } \\
\quad(\mathrm{n}=120)\end{array}$} & \multicolumn{2}{|c|}{$\begin{array}{l}\text { Negative control } \\
\qquad(\mathrm{n}=115)\end{array}$} & \multirow[b]{2}{*}{$P$-value } \\
\hline & Mean & $\mathrm{SE}$ & Mean & SE & \\
\hline $\mathrm{BHBA}(\mu \mathrm{mol} / \mathrm{L})$ & 906 & 46.5 & 1092 & 60.5 & 0.06 \\
\hline NEFA (U/L) & 0.84 & 0.028 & 0.82 & 0.076 & 0.83 \\
\hline Glucose $(\mathrm{mmol} / \mathrm{L})$ & 3.24 & 0.100 & 3.13 & 0.073 & 0.52 \\
\hline Cholesterol (mmol/L) & 1.90 & 0.024 & 1.77 & 0.021 & 0.0001 \\
\hline Urea $(\mathrm{mmol} / \mathrm{L})$ & 5.30 & 0.160 & 4.95 & 0.190 & 0.004 \\
\hline Calcium (mmol/L) & 2.19 & 0.026 & 2.17 & 0.021 & 0.125 \\
\hline Phosphorus (mmol/L) & 1.69 & 0.023 & 1.81 & 0.048 & 0.01 \\
\hline
\end{tabular}

${ }^{1}$ Models using proc genmod (SAS) included parity, BCS precalving, days from sample to calving, and the random effect of herd. 
Table 3. Number of positive milk ketone (Sanketopaper and Pink milk) tests obtained within $7 \mathrm{~d}$ after calving from cows either treated with a monensin-controlled release capsule (CRC) at 3 wk precalving or serving as a negative control. ${ }^{1}$

\begin{tabular}{|c|c|c|c|c|c|}
\hline Milk ketone test & Result & $\begin{array}{l}\text { Monensin } \\
\text { CRC }\end{array}$ & $\begin{array}{l}\text { Negative } \\
\text { control }\end{array}$ & $\begin{array}{l}\text { Odds } \\
\text { ratio }\end{array}$ & $P$-value \\
\hline Sanketopaper $(\geq 1)$ & Positive & 48 & 67 & 0.48 & 0.001 \\
\hline Sanketopaper $(\geq 2)$ & $\begin{array}{l}\text { Negative } \\
\text { Positive }\end{array}$ & $\begin{array}{r}72 \\
29\end{array}$ & $\begin{array}{r}48 \\
47\end{array}$ & 0.45 & 0.001 \\
\hline Pink Milk ${ }^{1}$ & $\begin{array}{l}\text { Negative } \\
\text { Positive } \\
\text { Negative }\end{array}$ & $\begin{array}{r}91 \\
7 \\
113\end{array}$ & $\begin{array}{r}68 \\
12 \\
103\end{array}$ & 0.48 & 0.02 \\
\hline
\end{tabular}

${ }^{1} P\left(\chi^{2}\right)<0.05$ for Sanketopaper but not for Pink Milk. Odds ratios and $P$-values generated from logistic regression model using Proc Genmod in SAS, controlling for BCS at treatment, parity, and the random effect of herd.

was $98 \%$. No significant effect of monensin CRC was detected for the Pink milk test when analyzed using the simple chi square statistic. However, there were significantly fewer positive Pink Milk tests in monensin-treated cows when analyzed using logistic regression (Table 3).

\section{DISCUSSION}

This study has identified several important findings with respect to the influence of a monensin CRC on metabolic parameters in Holstein dairy cows during the transition period. The serum biochemistry data collected from cows within $7 \mathrm{~d}$ precalving are particularly interesting because there is limited literature published on the influence of monensin for this important time period before parturition. Monensin CRC-treated cows had better energy status in the last week precalving, as indicated by significantly lower BHBA and NEFA, and higher cholesterol. The lower NEFA values indicate that there is less fat mobilization in these cows (Grummer, 1993), whereas the higher cholesterol values suggest that there is greater lipoprotein export from the liver (Gerloff et al., 1986; Kaneene et al., 1997). The data are consistent with Green et al. (1999) who reported a tendency for lower serum BHBA concentrations during the last $2 \mathrm{wk}$ precalving in cows treated with a monensin CRC at 3 wk before expected calving compared with placebo treated-cows. Neither NEFA nor cholesterol was measured in that study. The data are also supported by Stephenson et al. (1997), who reported that monensin CRC treated-cows had significantly lower BHBA and NEFA values precalving. However, those data were generated in only 24 cows from two dairy farms and they were managed under a pasture feeding system. To our knowledge, this is the first study of the use of monensin in periparturient dairy cows to assess its impact on serum cholesterol. The significantly higher concentrations of cholesterol in monensin treated-cows both pre and postcalving are sup- portive of improved energy metabolism in these cows (Gerloff et al., 1986; Kaneene et al., 1997). A previous study reported lower aspartate aminotransferase levels postpartum in cows administered monensin prepartum (Duffield et al., 1998a). This finding was attributed to improved liver function through reduced liver fat deposition. In the current study the results reflect less fat transported to the liver (lower NEFA precalving) combined with greater fat export from the liver (higher cholesterol) which supports the hypothesis that monensin inhibits accumulation of triglycerides in the liver of peripartum dairy cows.

Glucose concentrations were not significantly affected by monensin in the current study. However, numerical trends support previous studies. There may have been a lack of power to illustrate significant effects in the current project. Stephenson et al. (1997) reported that monensin CRC treated-cows had significantly lower glucose values in the immediate precalving period. Other researchers have reported significantly higher glucose concentrations in monensin treatedcows postcalving (Duffield et al., 1998a; Abe et al., 1994). There were numerical tendencies for both of these effects in this study.

The impact of monensin on urea has been previously reported in several studies. Stephenson et al. (1997) found higher urea levels in monensin treated-cows precalving which was also noted in this study. Others have reported higher urea levels in monensin-treated cows postcalving (Duffield et al., 1998a; Green et al., 1999). These effects on urea are thought to be a result of a protein-sparing effect in the rumen, resulting in an increased supply of amino acids to the small intestine. This results in a decreased negative nitrogen balance in transition dairy cows, and improved nitrogen utilization from feed (Plaizier et al., 2000). However, this effect may be dependent on the protein degradability of the diets that are fed, since it affects degradable rumen protein, rather than soluble or undegradable rumen protein. 
There appears to be no effect of monensin on calcium concentrations before or after calving. Other studies have reported similar results (Stephenson et al., 1997; Duffield et al., 1998a; Green et al., 1999).

The tendency for higher serum phosphorus concentrations in the precalving period, and significantly lower phosphorus postcalving in cows receiving a monensin CRC is difficult to explain. This may simply be a spurious result. It has not been identified in previous published studies, and does not have a logical physiological basis.

The lack of a significant effect for monensin on NEFA concentrations postcalving is expected and has been previously reported (Abe et al., 1994; Stephenson et al., 1997). The tendency for lower postpartum BHBA concentrations in monensin treated-cows is consistent with several studies demonstrating lower ketone concentrations in cows receiving monensin in the postcalving period (Sauer et al., 1989; Duffield et al., 1998a; Green et al., 1999).

Several measures were used to quantify subclinical ketosis in this study. Monensin CRC significantly reduced the incidence of positive urine ketones precalving. Although there were just 12 positive samples during this time period, only three were from cows that were treated with monensin. These data support the serum biochemistry findings of improved energy supply, and therefore a reduced risk of ketosis. The prevalence of subclinical ketosis measured via milk ketone tests using the Sanketopaper test and the Pink Milk test was significantly lower in monensin-treated cows. This result is also consistent with previous research (Duffield et al., 1998b) and indicates that cowside milk ketone tests can be used to identify changes in the herd incidence of subclinical ketosis associated with alterations in transition cow diets.

The calculated sensitivity and specificity for the two milk ketone tests used in this study clearly show a greater accuracy of the Sanketopaper test. The Sanketopaper test measures milk BHBA compared to the Pink Milk test, which measures milk acetoacetate. The performance of the Sanketopaper test in this study is consistent with other reports that have evaluated this test (Geishauser et al., 1998; Geishauser et al., 2000). The current evaluation of Pink Milk is consistent with findings that repeatedly demonstrate low sensitivity for nitroprusside-based milk ketone tests (Duffield, 1997; Geishauser et al., 1998). However, this result for Pink Milk contradicts a recent study where the test was found have a much higher sensitivity (76\%) (Geishauser et al., 2000).

\section{CONCLUSIONS}

This study has demonstrated that the monensin CRC can positively affect selected indicators of energy me- tabolism in Holstein dairy cows both pre- and postcalving, when it is administered $3 \mathrm{wk}$ before expected calving. Monensin CRC treated-cows had lower BHBA precalving and tended to be lower postcalving, lower NEFA concentrations precalving and higher cholesterol concentrations both pre and postcalving. In addition serum urea levels were elevated both pre and postcalving in monensin treated animals.

The prevalence of subclinical ketosis as measured by on-farm cowside tests was significantly lower in monensin treated-cows.

Monensin use for prevention of metabolic disorders in lactating dairy cattle is best introduced at the time of cows entering the close-up group rather than starting at the time of calving.

\section{ACKNOWLEDGMENTS}

We wish to thank Provel, a Division of Eli Lilly Canada Inc. for generous financial support of this project. In addition we wish to thank Jodi Wallace for her technical assistance.

\section{REFERENCES}

Abe, N., I. J. Lean, A. Rabiee, J. Porter, and C. Graham. 1994. Effects of sodium monensin on reproductive performance of dairy cattle. II. Effects on metabolites in plasma, resumption of ovarian cyclicity and oestrus in lactating cows. Aust. Vet. J. 71(9):277-282.

Duffield, T. F. 1997. Effect of a monensin controlled release capsule on energy metabolism, health, and production in lactating dairy cattle. D. V. Sc., Diss., University of Guelph, Guelph, Ontario, Canada.

Duffield, T. F., D. Sandals, K. E. Leslie, K. Lissemore, B. W. McBride, J. H. Lumsden, P. Dick, and R. Bagg. 1998a. Effect of prepartum administration of monensin in a controlled-release capsule on postpartum energy indicators in lactating dairy cows. J. Dairy Sci. 81:2354-2361.

Duffield, T. F., D. Sandals, K. E. Leslie, K. Lissemore, B. W. McBride, J. H. Lumsden, P. Dick, and R. Bagg. 1998b. Efficacy of monensin for the prevention of subclinical ketosis in lactating dairy cows. J. Dairy Sci. 81:2866-2873.

Duffield, T. F., K. E. Leslie, D. Sandals, K. Lissemore, B. W. McBride, J. H. Lumsden, P. Dick, and R. Bagg. 1999. Effect of prepartum administration of a monensin controlled release capsule on cow health and reproduction. J. Dairy Sci. 82:2377-2384.

Geishauser, T., K. Leslie, D. Kelton, and T. Duffield. 1998. Evaluation of five cowside tests for use with milk to detect subclinical ketosis in dairy cows. J. Dairy Sci. 81:438-443.

Geishauser, T., K. Leslie, J. Tenhag, and A. Bashiri. 2000. Evaluation of eight cow-side tests in milk for detection of subclinical ketosis in dairy cows. J. Dairy Sci. 83:296-299.

Gerloff, B. J., T. H. Herdt, and R. S. Emery. 1986. Relationship of hepatic lipidosis to health and performance in dairy cattle. JAVMA 188:845-850.

Green, B. L., B. W. McBride, D. Sandals, K. E. Leslie, R. Bagg, and P. Dick. 1999. The impact of a monensin controlled-release capsule on subclinical ketosis in the transition dairy cow. J. Dairy Sci. 82:333-342.

Grummer, R. R. 1993. Etiology of lipid-related metabolic disorders in periparturient dairy cows. J. Dairy Sci. 76:3882-3896.

Kaneene, J. B., R. Miller, T. H. Herdt, and J. C. Gardiner. 1997. The association of serum NEFA and cholesterol, management and feeding practices with periparturient disease in dairy cows. Prev. Vet. Med. 31:59-72. 
Plaizier, J. C., A. Martin, T. Duffield, R. Bagg, P. Dick, and B. W. McBride. 2000. Effect of a prepartum administration of monensin in a controlled-release capsule on apparent digestibilities and nitrogen utilization in transition dairy cows. J. Dairy Sci. 83:2918-2925.

Richardson, L. F., A. P. Raun, E. L. Potter, C. O. Cooley, and R. P. Rathmacher. 1976. Effect of monensin on rumen fermentation in vitro and in vivo. J. Anim. Sci. 43:657.
Rumensin CRC Veterinary Reference Guide, 1998. Provel, a Division of Eli Lilly Canada Inc., Research Park Centre, Guelph, Ontario, Canada N1G 4T2.

Sauer, F. D., J. K. G. Kramer, and W. J. Cantwell. 1989. Antiketogenic effects of monensin in early lactation. J. Dairy Sci. 72:436-442.

Stephenson, K. A., I. J. Lean, M. L. Hyde, M. A. Curtis, J. K. Garvin, and L. B. Lowe. 1997. Effects of monensin on the metabolism of periparturient dairy cows. J. Dairy Sci. 80:830-837. 